\title{
Erratum: Effect of GLP-1 receptor agonist treatment on body weight in obese antipsychotic-treated patients with schizophrenia: A randomized, placebo-controlled trial
}

To the Editor:

"Treatment of antipsychotic-associated obesity with a GLP-1 receptor agonist (GLP-1RA): The TAO trial" was the first clinical investigation of glucagon-like peptide-1 receptor agonist (GLP-1RA) treatment (exenatide $2 \mathrm{mg}$ once-weekly or placebo) in antipsychotictreated schizophrenia patients with obesity. ${ }^{1}$ Recently, we published the main results from the TAO trial as an original article in Diabetes, Obesity and Metabolism. ${ }^{2}$

We regret to report that further analyses of the TAO dataset have revealed an error in the secondary analyses presented in the original publication. Importantly, the error did not influence the results of the primary endpoint (change in body weight), showing that both patients treated with exenatide as well as the placebo group experienced significant $(P=.004)$ but similar weight losses of $2.24 \pm 3.3$ and $2.23 \pm 4.4 \mathrm{~kg}(P=.98)$.

The error specifically relates to our secondary analyses of the metabolic blood markers. In these analyses, the coding of "visit type" had been shuffled, and in turn, the data and statistical tests of the metabolic blood markers in Section 2.6.4 and Table 1 were based on incorrect visit types. ${ }^{2}$ Reductions in body weight are typically associated with improvement in metabolic blood markers, and our unexpected report of a post-intervention worsening of blood metabolic variables after 3 months, was therefore incorrect and misleading. Below, we present a corrected version of Table 1, and we also present a modified Results section. Finally, we briefly discuss the implications of these corrected secondary analyses.

\section{1 | CORRECTED RESULTS}

These corrected results correspond to the second paragraph Section 3.2 in the original paper. ${ }^{2}$ Changes are shown in italic font.

Plasma exenatide significantly increased in the exenatide group compared to the placebo group $(P=.002$; Table 1$)$. Exenatide treatment compared to placebo (Time $\times$ Group interaction) significantly reduced central 24-hour systolic blood pressure $(P=.004)$ and pulse wave velocity $(P=.007)$. A trend level Time $\times$ Group interaction was found for glycated haemoglobin (HbA1c [P = .063]), indicating that exenatide tended to lower $\mathrm{HbA1c}$ compared to placebo.
Significant effects of Time were found on central 24-hour systolic blood pressure $(P=.048)$, peripheral 24 -hour systolic blood pressure $(P=.03)$, fasting plasma glucose $(P=.006)$, plasma exenatide $(P=.002)$, triglycerides $(P=.044)$, total cholesterol $(P=.009)$, and HDL cholesterol $(P=.006)$. No significant effect of Time was found on LDL cholesterol $(P=0.289)$, and a trend level significant effect of Time was found for very low-density lipoprotein cholesterol $(P=.054)$. Regarding plasma exenatide, we found an effect of Group $(P<.001)$, but no effect of Group was found for any other secondary outcomes. Post hoc correction for smoking status did not significantly change results concerning any secondary outcomes.

\section{2 | IMPLICATIONS}

Regardless of treatment arm, the moderate weight loss of $2.3 \mathrm{~kg}$ over 3 months in the TAO study was associated with small reductions in fasting plasma glucose, triglycerides, total cholesterol and HDL cholesterol levels. At trend-level significance, we observed an indication of an $\mathrm{HbA1c}$-lowering effect of exenatide. Interestingly, 2 recently published studies in antipsychotic-treated patients with schizophrenia showed that GLP-1RA treatment improved blood metabolic markers and promoted weight loss., ${ }^{3,4}$ Because one study investigated exenatide $2 \mathrm{mg}$ once-weekly in clozapine-treated patients for 24 weeks, ${ }^{3}$ and the other study used liraglutide $1.8 \mathrm{mg}$ daily in patients with prediabetes treated with olanzapine or clozapine, ${ }^{4}$ further research is needed to determine the potential role of GLP-1RA treatment in antipsychotic-treated patients with obesity.

\section{3 | COMMENT}

The reported error had minor overall impact on our study; however, the premise for progress in research is the availability of accurate data, and our originally reported blood metabolic parameters were misleading. We have meticulously checked all analyses related to this study, and we confidently claim that no other mistakes are present. Please accept our sincere apologies for this unfortunate inaccuracy. 
TABLE 1 Biochemical fasting blood values

\begin{tabular}{|c|c|c|c|c|c|c|c|}
\hline & \multicolumn{2}{|c|}{ Exenatide $(n=20)$} & \multicolumn{2}{|c|}{ Placebo $(n=20)$} & \multirow{2}{*}{$\begin{array}{l}\text { Time } \\
P \text { value }\end{array}$} & \multirow{2}{*}{$\begin{array}{l}\text { Group } \\
P \text { value }\end{array}$} & \multirow{2}{*}{ Time $\times$ Group $P$ value } \\
\hline & Baseline & End-of-trial & Baseline & End-of-trial & & & \\
\hline $\begin{array}{l}\mathrm{HbA} 1 \mathrm{c}, \mathrm{mmol} / \mathrm{mol} \\
\text { [range] }\end{array}$ & $\begin{array}{l}35.95 \pm 3.60 \\
{[29-42]}\end{array}$ & $\begin{array}{l}34.00 \pm 3.39 \\
{[29-42]}\end{array}$ & $\begin{array}{l}35.75 \pm 4.96 \\
{[28-47]}\end{array}$ & $\begin{array}{l}38.3 \pm 13.58 \\
{[27-93]}\end{array}$ & .800 & .337 & .063 \\
\hline $\begin{array}{l}\text { Fasting plasma glucose, } \mathrm{mM} \\
\text { [range] }\end{array}$ & $\begin{array}{l}5.46 \pm 0.55 \\
{[4.2-6.5]}\end{array}$ & $\begin{array}{l}5.26 \pm 0.36 \\
{[4.3-5.9]}\end{array}$ & $\begin{array}{l}5.71 \pm 0.86 \\
{[4.8-8.3]}\end{array}$ & $\begin{array}{l}5.39 \pm 0.44 \\
{[4.8-6.4]}\end{array}$ & $.006 *$ & .254 & .519 \\
\hline $\begin{array}{l}\text { Plasma exenatide, } \mathrm{pmol} / \mathrm{L} \\
\text { [range] }\end{array}$ & $\begin{array}{l}3.4 \pm 10.5 \\
{[0-40]}\end{array}$ & $\begin{array}{l}84.9 \pm 29.6 \\
{[65-147]}\end{array}$ & $\begin{array}{l}0.0 \pm 0 \\
{[0-0]}\end{array}$ & $\begin{array}{l}1.1 \pm 3.2 \\
{[0-11]}\end{array}$ & $.002 *$ & $<.001 *$ & $.002 *$ \\
\hline $\begin{array}{l}\text { Plasma glucagon, pmol/L } \\
\text { [range] }\end{array}$ & $\begin{array}{l}3.75 \pm 13.1 \\
{[0-58]}\end{array}$ & $\begin{array}{l}17.8 \pm 19.1 \\
{[0-50]}\end{array}$ & $\begin{array}{l}0.0 \pm 0.0 \\
{[0-0]}\end{array}$ & $\begin{array}{l}0.0 \pm 0.0 \\
{[0-0]}\end{array}$ & $.004 *$ & $<.001 *$ & $.004 *$ \\
\hline $\begin{array}{l}\text { Triglyceride, } \mathrm{mmol} / \mathrm{L} \\
\text { [range] }\end{array}$ & $\begin{array}{l}2.12 \pm 1.07 \\
{[0.65-4.47]}\end{array}$ & $\begin{array}{l}1.86 \pm 0.93 \\
{[0.57-3.66]}\end{array}$ & $\begin{array}{l}1.76 \pm 0.97 \\
{[0.52-4.31]}\end{array}$ & $\begin{array}{l}1.63 \pm 0.94 \\
{[0.44-3.51]}\end{array}$ & $.044 *$ & .335 & .510 \\
\hline $\begin{array}{l}\text { Total cholesterol, } \mathrm{mmol} / \mathrm{L} \\
\text { [range] }\end{array}$ & $\begin{array}{l}5.04 \pm 1.06 \\
{[3.0-7.0]}\end{array}$ & $\begin{array}{l}4.84 \pm 1.16 \\
{[2.8-7.7]}\end{array}$ & $\begin{array}{l}4.86 \pm 0.95 \\
{[2.5-6.9]}\end{array}$ & $\begin{array}{l}4.57 \pm 0.75 \\
{[3.2-6.7]}\end{array}$ & $.009 *$ & 0.449 & .617 \\
\hline $\begin{array}{l}\mathrm{HDL} \text { cholesterol, } \mathrm{mmol} / \mathrm{L} \\
\text { [range] }\end{array}$ & $\begin{array}{l}1.03 \pm 0.22 \\
{[0.56-1.39]}\end{array}$ & $\begin{array}{l}0.98 \pm 0.22 \\
{[0.61-1.60]}\end{array}$ & $\begin{array}{l}1.10 \pm 0.31 \\
{[0.66-1.82]}\end{array}$ & $\begin{array}{l}1.01 \pm 0.26 \\
{[0.58-1.51]}\end{array}$ & $.006 *$ & .498 & .420 \\
\hline
\end{tabular}

Abbreviations: HbA1c, glycated haemoglobin ( $<42 \mathrm{mmol} / \mathrm{mol}$ indicates normoglycaemia; $42-47 \mathrm{mmol} / \mathrm{mol}$ indicates prediabetes and $>48 \mathrm{mmol} / \mathrm{mol}$ indicates diabetes); VLDL, very low density lipoprotein. Values are mean $\pm S D$, with range (in square brackets). $P$ values were analysed using repeatedmeasures analysis of variance, and significant group differences are indicated by asterisks (*).

May this attempt to provide transparency not compromise confidence in the presented data.

\section{ORCID}

Bjørn H. Ebdrup (DD) http://orcid.org/0000-0002-2590-5055

Filip K. Knop (D) http://orcid.org/0000-0002-2495-5034

Bjørn H. Ebdrup MD ${ }^{1,2}$ (D)

Brian V. Broberg $\mathrm{PhD}^{1}$

Pelle L. Ishøy $\mathrm{MD}^{1}$

Nikolaj Bak $\mathrm{PhD}^{1}$

Ulrik B. Andersen $\mathrm{MD}^{3}$

Niklas R. Jørgensen $\mathrm{MD}^{4,5}$

Jens J. Holst $\mathrm{MD}^{6}$

Filip K. Knop MD $2,6,7$ (D)

Birte Y. Glenthøj $\mathrm{MD}^{1,2}$

${ }^{1}$ Centre for Neuropsychiatric Schizophrenia Research, CNSR, and Center for Clinical Intervention and Neuropsychiatric Schizophrenia Research,

CINS, Mental Health Centre Glostrup, University of Copenhagen,

Glostrup, Denmark

${ }^{2}$ Department of Clinical Medicine, Faculty of Health and Medical Sciences, University of Copenhagen, Copenhagen, Denmark ${ }^{3}$ Department of Clinical Physiology, Nuclear Medicine \& PET,

Rigshospitalet, University of Copenhagen, Glostrup, Denmark ${ }^{4}$ Departments of Clinical Biochemistry and Medicine, Research Centre for Ageing and Osteoporosis, Rigshospitalet, University of Copenhagen,

Glostrup, Denmark

${ }^{5}$ OPEN, Odense Patient Data Explorative Network, Odense University Hospital/Institute of Clinical Research, University of Southern Denmark,

Odense, Denmark
${ }^{6}$ Novo Nordisk Foundation Centre for Basic Metabolic Research, Faculty of Health and Medical Sciences, University of Copenhagen, Copenhagen,

Denmark

${ }^{7}$ Centre for Diabetes Research, Gentofte Hospital, University of Copenhagen, Hellerup, Denmark

Correspondence

Dr Bjørn H. Ebdrup MD, PhD, Center for Neuropsychiatric Schizophrenia Research, CNSR, and Center for Clinical Intervention and

Neuropsychiatric Schizophrenia Research, CINS, Copenhagen University Hospital, Mental Health Centre Glostrup, Nordre Ringvej 29-69,

DK-2600, Glostrup, Denmark.

Email: bebdrup@cnsr.dk

DOI 10.1111/dom.13204

\section{REFERENCES}

1. Ishøy PL, Knop FK, Broberg BV, et al. Treatment of antipsychotic -associated obesity with a GLP-1 receptor agonist-protocol for an investigator-initiated prospective, randomised, placebo-controlled, double-blinded intervention study: the TAO study protocol. BMJ Open. 2014;4(1):e004158.

2. Ishøy PL, Knop FK, Broberg BV, et al. Effect of GLP-1 receptor agonist treatment on body weight in obese antipsychotic-treated patients with schizophrenia: a randomized, placebo-controlled trial. Diabetes Obes Metab. 2017;19(2):162-171.

3. Siskind D, Russell AW, Gamble C, et al. Treatment of clozapineassociated obesity and diabetes with exenatide (CODEX) in adults with schizophrenia: a randomised controlled trial. Diabetes Obes Metab. 2018;20:1050-1055.

4. Larsen JR, Vedtofte L, Jakobsen MSL, et al. Effect of Liraglutide treatment on prediabetes and overweight or obesity in clozapine- or olanzapine-treated patients with schizophrenia spectrum disorder. JAMA Psychiat. 2017;74(7):719. 